\title{
The Empire of Songhay, 1375-1591: Memory and Heritage of a Glorious Past [A Historiographical Essay]
}

\author{
George Kintiba, Ph.D. \\ University of Maryland \\ College Park, MD
}

\section{Introduction}

This is a historiographical essay on the empire of Songhay ${ }^{1}$ (1375-1591), one of the greatest Middle Ages African empires of West Sudan. It is important that we highlight from start two reasons that birth this article: the growing interest to revive untold aspects of African glorious past and African historiography debate. African history does not start with the colonial period as we were instructed in the halls of European academia, but its roots go back to the beginning of human history.Its historiography is still set to its infancy stage, compared to European and American historiographies, and calls for a strong interdisciplinary approach today in order to make it relevant and attractive (Lonsdale 1981; Masonen 2000). The reasons attributed to this infancy stage are multiple. PekkaMasonen stresses at least two important reasons: the marginalization of Africa and the great fascination with the marvels of the mid-sixteenth century Europe to East Asia and to the New World. By the Mid-sixteenth century, the majority of European readers lost interest in African because of the great fascination with the marvels of East Asia and the New World. This marginalization of Africa in European geographical study expands well into the nineteenth century. Most of the work describing Africa focused on the Barbary Coast ... More work and compilations, on Africa, were nothing but a re-stating of the earlier material (PekkaMasonen 2000, 246).Another important indication to this infancy stage, says Masonen, goes back to the seventeenth century Europe in the way the visits of envoys of African rulers were received in European courts. The meaning of these visits in European academic circles has remained unnoticed by contemporary writers, especially when compared to the popularity and interest afforded to such empires and delegations from the Ottoman, the Siamese or of the Persian ambassadors.

John Lonsdale points to the colonial element as a living denial carried on as chronicles of injury and not of pride, and as engines of oppression and not of civilization (Lonsdale 1981). He also ties it to the changing preoccupations of early historians of Africa and the place afforded to such an enterprise within the humanities in general. Dierk Lange (1994) attributes that stage to a triple earlier cause (emphasis mine):

(1) the virtual impossibility to assess the validity of sources and early traditions;

(2) the impossibility of establishing any synchronism between two closer historical events and the non-existence of clearly recognizable periods of early history, and;

(3) the impossibilities to discover behind the midst of legends and the invocative names the distinctive features ofold and important dynasties.

For this latter, Lange refers to the mystery surrounding the foundation of some African kingdoms and the difficulty to perceive disruptions within dynastic reigns. All the above reasons explain the choice afforded to studies in political science as the initial disciplines to launch African History. The selection of political science as the initial scholarly ground for African History rested on the premises that Political science addressed the stateformation as an achievement, which is chronologically identifiable. Soyinka, Wrigley, Chanock, Markovitz, and Uzoigwe would dismiss this concept of state-formation and the notion of statelessness for they do not advance the debate and maintain the push for a historiography of Africa as not valid. This position is no longer defendable because Africa has been writing since antiquity ${ }^{2}$ and had great empires, kingdoms, and states that rose and created great civilizations from immemorial time to the contact with Europeans and the Arab world.

\footnotetext{
${ }^{1}$ In this entire article we chose the spelling Songhay over Songhai in order to have uniformity with the majority of our sources.

${ }^{2}$ Africa has a long history connected to writing from antiquity to the time Europeans started to penetrate Africa hinterland. African scripts which reading codes have been broken continue to give clear proof of African contributions to the world of 
Soyinka, Wrigley, Chanock, Markovitz, and Uzoigwe suggest the social processes because African contribution to humanity has been the civilized art of living fairly in peace together not in states (for early protests, see Soyinka 1967; Wrigley 1971; Chanock 1972; Markovitz 1977, 25-55; and later, Uzoigwe 1980, 115). Because of the law of ideological gravitation, African studies, its historiography in particular, were relegated to the bottom. But today's discovery as the Sudanic Africa ${ }^{3}$ puts to rest not just the notion spread by Westerners that SubSaharan Africa lacked a tradition of literacy prior to the era of European colonization. It also gives to scholars, especially historians in our context, new fields of research that expand from politic to social structures, from anthropology, theology, jurisprudence, social environment and far beyond. In other words, any historical process that is opened to what John Lonsdale calls axiomatic uncertainties should be able to ward off the dogmatic error that saw in European scholarship the sole norms for erudition: that African categories are not system of regression but fields of opportunities. Thus an element in the revival of African history, which explains the genesis stage of its historiography! Another area of a more general controversy in African historiography lies in the mischaracterization of African history as idealistic (Lonsdale 1981; Hunwick 1996). This point is attributed to the way the past and present changes are measured against contemporary hope.

The paper is divided in two sections. In the first part, we gaze at the Songhay space as we try to sketch a picture of the shift that took place in its population. The establishment of the people in the region, the change of power from one group to another and the impacts on the political map of the Songhay will be highlighted. We will draw on different arguments, for and against, used by different scholars as they wrestle with different hypothesis and sources to make the Songhai story find its proper place and context within the map of the Middle Ages Africa West Sudan.

knowledge. Egyptian Hieroglyphs is the first and undisputable script that birthed a new scientific field of knowledge (for more on the contributions of Pharaonic Egypt, read: Herodotus, History of Herodotus. Vol. 1 and Cheikh Anta Diop, Antériorité des Civilizations Nègres). The Tifinagh script used by the Berber and Tuareg ( $2^{\text {nd }}$ century C.E.), the Ethiopian alphabet $\left(4^{\text {th }}\right.$ century C.E.) used to write the Ge'ez, the Punic alphabet in use in North African and spread to Spain, Italy and France $\left(9^{\text {th }}\right.$ century C.E.), the Yoruba alphabet (1846) and the Bamum script (1896) under king (sultan) Ibrahim Njoya of Cameroon are few indisputable examples. The recent discovery of the Sudanic Africa documents of Middle Age West Sudan, by Professor John Hunwick, is another proof that Africa is a continent with a written history. Herodotus, who was not a passive reporter of incredible tales and rubbish, but a scrupulous, objective and scientific man of his time, had already rejected any account that denied and negated Africa (Black Egypt) the right and a history of writing. From his eyewitness account, Herodotus informed us, with a rare honesty for a Greek, that his country (Greece) borrowed from Egypt all elements of its civilization and concluded that Egypt was the cradle of civilization (Herodotus, Book II). Even after Alexander the Great enacted his policy of assimilation in Egypt (332 BCE) allowing crossbreeding between white Greeks and black Egyptians, Herodotus pointed with much precision that Egypt had been black. It was the native Egyptians (Blacks) who produced the civilization of Egypt with its writing (Herodotus, Book II). Christiane Desroches-Noblecourt talked about it when she wrote about the excavations in Tanis - the Biblical Zoan at the mouth of the eastern branch of the Nile Delta. Pierre Montet has just proved once again that The Father of History did not lie (Montet 1951) from his affirmations on black Egyptians: their contributions to the intellectual rise of Greece. Many African kingdoms, empires and chieftaincies either hid their written scripts, alphabets, or syllabaries for fear of the colonizers or the same European colonizing powers crushing them. The fear of a complete loss or annihilation forced Africans to keep the reading codes of their alphabets or syllabaries secret. This explains today's reasons African alphabets, scripts, and syllabaries reading codes have remained unbroken. Many of them are living scripts opened only to small tight circles of initiated people whose tasks are the transmission of existential societal information not reserved to outsiders.

${ }^{3}$ Sudanic Africa is this region of Sub-Saharan Africa in the Sahel that experienced the religious, cultural, and political influence of Arabs in the aftermath of the founding of Islam in the seventh century. The Sahel is spread across the countries that either intersect or border the Sahara desert's southern boundaries. The Sudanic Africa is also identified as this rich tradition that took root with generations of black Africans becoming proficient in speaking, reading, and writing Arabic, which enabled the writing of native African languages in Arabic scripts. In the Sudanic Africa are found these private collections of families that include letters, books, and book fragments on theology, jurisprudence, family and clan history, social environment, and African history. The influence of the Sudanic documents have remained marginal to society and collapsed with the cities where they flourished because at that time they were elitist and urban, written down in a language that did not take into account the autochthonous languages and cultures. It was professor John O. Hunwick, now director of Northwestern University's Institute for the Study of Islamic Thought in Africa (ISITA), who first came in contact with some Sudanic texts. Invited to the home of a Malian friend, while in Timbuktu in August 1999, Hunwick was shown this collection of 3,000 documents, many of which dated back to the $16^{\text {th }}$ century. But Hunwick attests his knowledge of the existence of these Sudanic texts and his work on them since the 1960s. 
The second part describes Songhay social order, mobility, trade and slavery with their implications that led to thedecline of the empire of Songhay. It is at this point that we will include our contribution to the historiography of the empire of Songhay, which is a huge and fascinating subject in itself.

Our attempt which gives itself as a partial view of a large, absorbing, and controversial matter - is not exhaustive but will use the following publications, generalizing and more specific works, as our backdrop (Ajayi and Crowder, 1985; Hunwick, 1966, 1972, 1996 and 2000; LansineKaba, 1977, 1978, 1984; Levtzion and Hopkins, 1981; Meillassoux, 1986; PekkaMasonen, 2000; Ki-Zerbo, 1997; Dupuis-Yakouba, 1911; Humphrey, 2001; Kake, 1976; Lange 1994, Diop 1967, and our West Africa to 1800 class, Fall 2015). The politics of Songhay's formative revolution appears to be too abstractly autonomous, too manipulatively intelligent as the Songhay people tried to muse their way to independence from the declining great empire of Mali while they sought to gain control over the Sahara trade and expand their influence to the neighboring people (Kaba 1977, 27; West Africa to 1800 class note, Howard University Fall 2009). Their rise as a homogeneous unit is deeply connected with the causative connections between asserting their power by bringing all Songhai dominant groups into one cohesive unit and the processes of drawing the surrounding states toward a common society.

\section{Gazing at the Songhay Space: Rise and Decline of an Empire}

A gaze into any so-called primitive society space,PlacideTempels suggests after his discovery of the concept la force vitale ${ }^{4}$ in the African cosmology, entails few crucial mental exercises. The first is to cast out any European post-Socratic visions in order to make an attempt to enter the world of the other from the other's perspective. Olivier Pétré-Grenouilleau suggests that in order to access the world of the other, one must, without reservation, accept to go far beyond the frontiers between the "relative" Other and the "Absolute" Other (Pétré-Grenouilleau 2004, 19)and embrace the self in the other. For the Songhay, space was never a static reification of the social order; rather it was viewed as an object linked dynamically to one own consciousness. The second is MerleauPonty's expansion of the concept space as a universal force that has dynamic sociological implications. This dynamic aspect, for the Songhay, is seen in terms of its political implications. The Songhay space or polity came into existence as early as the seventh century in the area of the great bend of the Niger River and its influence appears to be a result of the fusion of diverse Songhay subgroups into one homogeneous unit - the Sorko, fisherfolk; the Gabibi, farmers; the Bozo, and the Zarma. Long before gaining their autonomy as a people and building a most powerful empire during the Middle Ages West Sudan Africa, the Songhai were part of the great empire of Mali until the fourteenth century. Songhay Empire expanded in all directions until it stretched from central Niger and northwest Nigeria to the Atlantic Ocean (modern Senegal and Gambia). In other words, Songhay space encompassed today's West African nations' territories of Niger, Nigeria, Mauritania, Mali, Burkina Faso, Benin, Guinea, Guinea-Bissau, Senegal and Gambia.

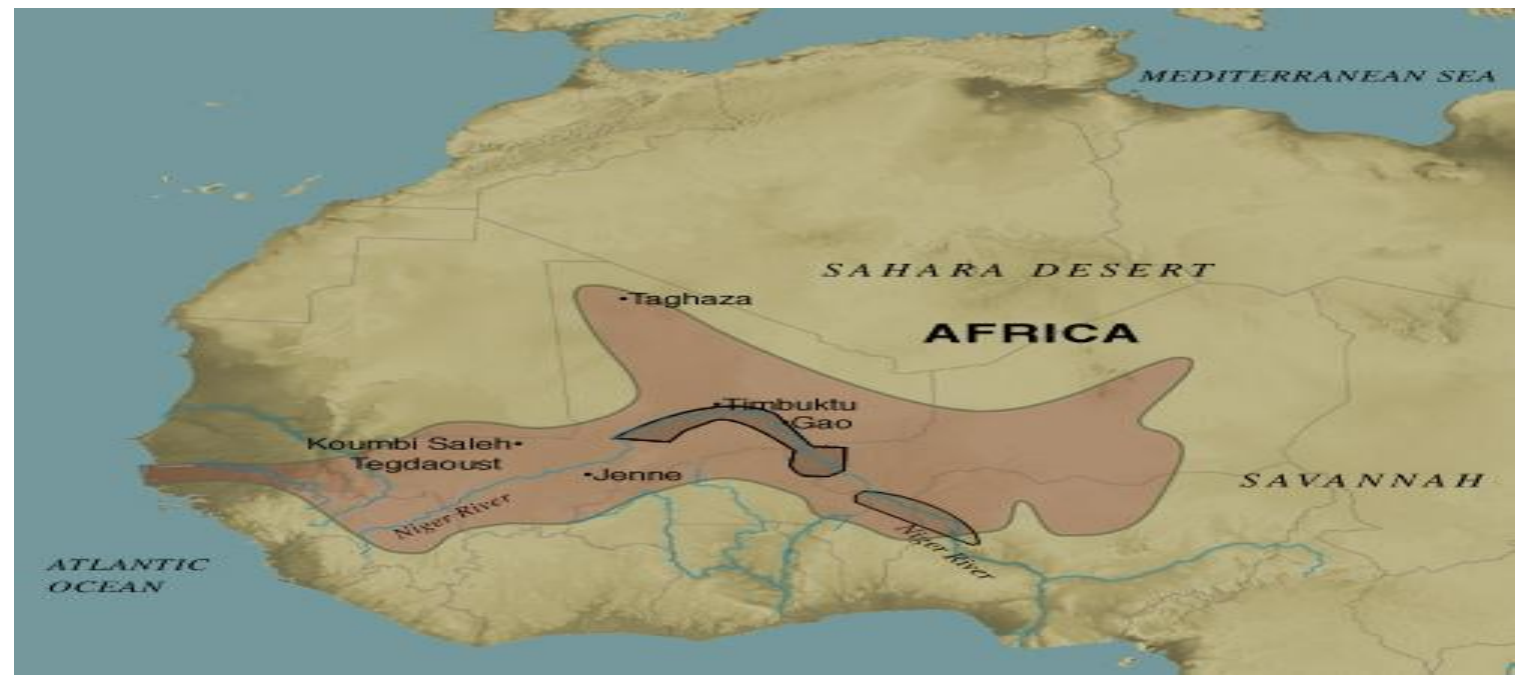

${ }^{4}$ La force vitale is this relational web that connects the African to the visible and invisible world without which, says Father PlacideTempels, la vie africainediminue(African life shrinks or better ceases to be). PlacideTempels came to discover this dynamic concept in African life after forty years of observation and comparison of the world of an African to that of an European as well as the way these two worlds order their sociology. 
The Empire of Songhay, 1375-1591

Image Courtesy of The Metropolitan Museum of Art, Heilbrunn Timeline of Art History, Image () The Metropolitan Museum of Art

By tracing their origin back to the latter part of the seventh century, historians suggest that a migration took place, but their opinions are divided at the place where that migration originated. The most attested is a migration from Libya to West Sudan. A certain AlimanDia, reputedly a Berber from Libya, eventually conquered the people living along the banks of the Niger River south of the present-day Gao (Republic of Mali). AlimanDia settled along the Niger River and established the Dia (or Za) dynasty of Songhay. The rise and fall of both preceding empires of Ghana and Mali did not alter the Dia people composition until the latter part of the thirteenth century when Ali Kolon, founder of the Sonni dynasty, made his first attempt to free the Songhay from the yoke of the Malians (Dupuis-Yakouba 1911, Hunwick 1985, Rose and Stoller 1989, Ki-Zerbo 1997, and later Appiah and Gates 2005).

Ali Kolon and his descendants took the title of Si or sonnito differentiate from the Dia and consider themselves a new Songhay dynasty. This separation was short lived for the Malians reestablished their hegemony over Songhay. Ki-Zerbo and Niane, adding an old source the report from Boubou, stresses the warrior nature of the Songhay from Kukiya, whom under SonniMadawu brought back twenty-four slave clans from a raid to the neighboring people. The incorporation of these twenty-four clans within the Songhay rank played an important role on the increase of the Songhay monarchy's scope for action. It was only with the ascendance of Sonni Ali Ber (1464-1491) that the Songhay regained total independence from Mali (Stoller 1981, Ki-Zerbo 1997). Baba Kake postulates that if Mali was the most prestigious of all West African empires of the Middle Ages West Sudan, Songhay was the most powerful (Kake 1976).

Before we can attempt to expand on the Songhay's mobility and fusion into one well-organized political unit, it is important that we address the twelfth century kingdom of Gao and the decline of the empire of Maliwithout which the first period of Songhay will remain obscure despite the presence of few chronicles and traditions. John Hunwick, who has specialized in Songhay history, writes about the city of Gao according to Arabic sources of the tenth and eleventh centuries that the early account of the Ibadi state of Tahert, written by Ibn al-Saghir c.290/9023 , indicates that soon after the foundation of Tahert routes were opened up for trade with bilad al-Sudan and mission was sent to one of the Sudanic rulers by the Imam Aflah b. Abd al-Wahhab ... 'Jawjaw' is probably an attempt to write the name 'Gawgaw', of which the most common Arabic orthography is 'Kawkaw'. 'Gawgaw' is itself a reduplicated form of the name 'Gaw', which is nowadays spelt 'Gao' (Hunwick 1985, 3). Based on these Arabic sources of the tenth and eleventh-century, historians agree that the city of Gao was established on the bank of the Niger River. It was a city made up of two linked towns - the rulers and the courts stayed on the west bank of the river and the Muslims occupied the east or the left bank (West Africa to 1800 class, note week VI Fall 2009; Hunwick 1972; Lange 1994, Ki-Zerbo 1997; Ajayi and Crowder 1985; Dupuis-Yakouba 1911). Arabic chronicles written in Timbuktu around 1657 and 1669, attested toGaobeing as a commercial emporium of international fame (Hunwick 1985, 4). The chief commodity found in Gao was gold, but the early auriferous regions were located far to the west of Gao in Bambuk and Bure on the Upper Niger region.

Hunwick, referring to his Arabic sources of the early tenth and eleventh centuries, affirms the non-existence of routes leading south from Gao; other historians point Gao as an absolute terminus so far as the great trading network of Arab merchants was concerned (Kaba 1978, 1984; Levtzion and Hopkins 1981; Meillassoux 1986; Dupuis-Yakouba 1911; Humphrey 2001; Kake 1976). But John Hunwick and Dierk Lange challenge each other on affirmations related to the identity of the rulers of Gao-Sane and the first dynasty establishment on the bank of the Niger River. Dierk Lange charges Hunwick with a neglect to acknowledge the sources of his reformulations. Hunwick, Lange continues, has discarded off-hand and against better evidence the identification of Yama b. K.ma (Lange 1994,279), which is the only possibility of correlating the internal with the external evidence. Lange invites the reader to use proper assessment of the earlier synchronism available in West Africa history, especially referring to the findings and publications of Jean Sauvaget, the first Orientalist to study the royals epitaphs of Gao-Sane, published thirty two years earlier ${ }^{5}$.

\footnotetext{
${ }^{5}$ Jean Sauvaget published his Notes préliminariessur les épitaphes de Gao in La Revue des Etudes Islamiques, pp. 7-8, in 1948. His second study, Les épitaphesroyales de Gaoin Al-Andalus, XIV, 123-41, was published in 1949. This same article was printed as well in Bulletin de l'IFAN, XII (1950), 418-40.Hunwick'sGao and the Almoravids: a hypothesis, in
} 
These sources that Hunwick neglects to attribute to Jean Sauvaget in his reformulation of the conquest theory are: (1) the Zaghe were part of the Sanhaja diaspora - and therefore apparently not invading foreigners ('Gao revisited' 269; Gao-Sane', 266-7; (2) the Zaghe may have been absorbed into the local community ('Gao revisited', 252; 'Gao-Sane', 265); (3) the succession of the early Zaghe kings was non-dynastic ('Gao revisited', 265; 'Gao-Sane', 263 (Lange, 1994, 279). There are also Sauvaget'sthe relations between Gao and Almeria found in Gao revisited, 264 and Epitaphes, 132-3. Among Hunwick'sother non-acknowledged sources are the 1912 publications of Delafosse ${ }^{6}$.

\section{From Gao and beyond}

On the historical reconstruction of the city of Gao, Lange defends the idea that the rise of Zaghe kings of GaoSane as the reason for the eclipse of the Zas and the implantation of a new royal clan, but it did not annihilate the Mande dynasty, nor did it change the Mande identity of the society (Lange 1994, 281). Hunwick, on the other hand, stresses a short significant effect of the Sanhaja conquest of the kingdom of Gao, since the Sanhaja kings are supposed to have disappeared in one way or another in the course of the twelfth century (Hunwick 1994, 256). This Hunwick-Lange disagreement is very pronounced on the ground of the overall ethnic identity of the pre-AskiyaGao society. Lange argues for the pre-fifteenth century eastern Niger bend as part of the Mande world whose identity was changed only at the beginning of the fifteenth century with the arrival of the Sorko in the region. Hunwick uses the established theory of tribal stability among the Wangara and the Zaghay to prove a short lived influence of the new comers in the region and insists on their assimilation within the bigger group or the first inhabitants. Above all, our intake in these scholars' divergences will suggest that the ethno-genesis of African people, in general, is dealt adequately by correlating the internal and the external evidence while maintaining Tempels' advice to create a balanced inquiry — nothing can be achieved without an open mind and the need of casting out any European post-Socratic visions. For the historian of medieval Africa, any approach whether taken in a spirit of collegiality or defensive and personal intuition must be able to relate critical elements of internal evidence to the evidence made available by external sources. Although there is no absolute safeguard against the pitfalls of speculation and circular reasoning, the investigator... should consider the general plausibility of the resemblance between individual terms by taking into account their meaning and their historical context (Lange 1994, 282).

Ki-Zerbo suggests that the city of Gao was located on the bank of the Niger River as it faced the immensity of central Sudan. In the twelfth century, Gao became the capital of the newly established Songhay empire (emphasis mine). Many historians attest toGao taking precedence over the old city of Kukiya as an important cosmopolitan city, especially because of the Saharan trade with salt coming from the desert, merchandise from Egypt, Lybia, Ifrikiya via Tadmekka and Tuwat. Gao reputation in that period is attested by Al-Bakri and Al-Idrisi reports, in which both cities stood as well-protected towns surrounding with big wall (Ki-Zerbo 1997, 77; also attested by Jansen 2002, Davidson 1998, Masonen 2000, Levtzion and Spaulding 2003, Caillie 1965, and Bouvill 1968). Dierk Lange, expressing the need to respond to the criticisms voiced by Hunwick on his intake on the location of Gao, deals with the question in relation to topics that overlap successive periods: the Qanda as well as the Zaghe/Sunni period, the impact of Ghana/Old Mali on Gao, the identification of the first Songhay polity, the dynastic history of Gao in relation to the expansion of Mali in the fourteenth century, and finally the coming of the Songhay in the fifteenth century. In his approach to respond to the topic of the location of Gao, Lange sought a response in relation to his study done on the epitaphs of Gao-Sane and the question of Songhay ethnicity. The epitaphs of Gao-Sane suggest that a new dynasty, the Zaghe, came to power around 1080 and the residence of the kings was Gao-Sane. The reports of al-Idrissi, of 1154, confirm that the rulers of Gao were, indeed, residing not on the banks of the river, but close to a canal (khalidj) of the river in Gao. Al-Idrisi's reports, says Lange, gave him reasons to assume that the city was also the seat power of the pre-AlmoravidQanda in Old Gao on the left bank of the Niger River, which was also easy for foreign traders to reach.

B.Swartz and R. Dumett (eds), West African Culture Dynamics, 251-75 in which he deals with the points that Lange brings to the reader's attention was published in 1980.

${ }^{6}$ Lange, in addition, points the reader to Hunwick self-attribution of Delafosse's ideas as his own. Delafosse published his findings of the seventh/eighth century expansion of the Songhay from Dendi to Gao in his two volumes Haut-SénégalNiger in 1912. For a detailedinformation on the debate related to the use and acknowledgement of sources between Lange and Hunwick, please see Dierk Lange's 'From Mande to Songhay: Towards a political and ethnic history of medieval Gao', JAH, 35 (1994), 275-300. 
An important addition is the agreement of many early Arabic reports, which distinguish two separate parts of the cities: the town of the king on one bank and a town of the traders, Sarnah, on the other bank of the city. It is important to note that Gao became an influential city because of the attention afforded to it by the Berberophone nomad, especially with the salt commerce of the tenth and eleventh centuries coming down from Tilemsi.

The proximity between Gao and Kukiya enables the trade of saltdown the river where Sudanic products useful to nomad might be obtained: mats, gourds, wax, honey, iron goods and perhaps cloth. Above all such trade gave increased access to grain (Hunwick 1985, 5). Gao was first controlled by the Zas (Za) or Ja (Dia) dynasty whose cradle Hunwick points to beingKukiya, but Lange highlights its Malian origin. Early in the third quarter of the ninth century Gao, says Hunwick, was the seat power that commanded the allegiance of a number of neighboring peoples and probably came to be controlled by the Zas of Kukiya at a time when trade along the Gao-Kukiya axis had become a significant factor in the prosperity of this first Songhay state (Hunwick 1985, 7). Ki-Zerbo suggests its probable Songhay origin whose ancestors intermarried with the Berbers. Historians agree on the twelfth century as the time that Gao became the capital of the newly established Songhay state, which ended up by eclipsing the old city of Kukiya as Arabs authors called it. Kukiya was maintained as the ancestral capital for the Songhay while the newly capital of Gao stood as the political and the economical center. The foundation of the Songhay kingdom, according to all recorded sources, Arabic and travelers, placeKukiyato be the cradle of the Songhay and does not involve the crossing of the Niger River. It was under this first dynasty, the Ja, that Islam was introduced to the court of Songhay, but its influence remained peripheral because the mass of the people remained faithful to their ancestral religion (West Africa to 1800 class, note of week VI). The first evidence of a profound Islamic faith imported to Songhay is attested by the funerary stelae of Gao. Dierk Lange used these stelae extensively to study the influence and chronological dynasties of Songhay.

\section{Songhay Society and Politics}

At the end of the thirteenth century Mali conquered the kingdom of Gao, but the Jaa did not hesitate to shake things off on special occasions in order to gain their independence. In 1335 the Songhay broke away from Mali and began to conquer the surrounding area with a well-trained army and cavalry. It wealth came from the Sahara trade in salt and gold, especially through the great trading cities of Gao, Djenne and Tombouctou (Appiah\& Gates 2005, 497). The fourteenth century reports of Ibn Battuta and IbnKhaldun refer to the Sunnis as part of the Songhay and affirm that the Sunni kings had to struggle against the Malians in order to assert their power. Before dealing in more detail with the Songhay society, it seems important to alert our readers that the ethnonym study advocated by some historians turned our attention for a while to the strange similarity between Zas, Zaghay, Zaghawa and Zaghe. Extended arguments from historians support the conclusions that all three names refer to an entity of Songhay. This identification to the Songhai root is very important because it tells that the name Za and all its different forms recorded in various texts refer to one and same, presumed, royal ancestor.

This interchangeability is to be understood in the context of the plural marker of the languages spoken in the Middle Niger. Who then was the alleged royal ancestor of the Songhay? John Hunwick, Chanock, Markovitz and many historians, founding their arguments on Dupuis-Yakouba early research of 1911, convey that in a number of West African societies the same Za as the Zaghe and the Zaghay, of external sources, have a close association with kingship. For the Yoruba and the Kotoko of Gawi it refers to an early ruler or a founding hero, in Borno and in Darfur it is a praise-name of the ruler, in Soninke it is a royal title, in Kebbitunnkara is an epithet of the sole remaining titleholder of the erstwhile royal Lailabawa and in Songhaydunka has the meaning of 'chief' while jeseredunka designates the 'griot' of the king (Dupuis-Yakouba 1911, 22). This Songhay kingship title also has a religious meaning for the king is not only the royal ancestor but he is also connected to the institution of divine kingship. Here one can tell that the Songhay is a patrilineal society. (West Africa to 1800, class note week V; Rouch 1960; Wilks 1993).

According to both traditions and chronicles related to the Songhay, the Za was the first Songhay dynasty, who in the fourteenth century was subdued by the Sunni Ali Kolon. This latter freed the Songhay from the yoke of the Mali Empire and is viewed as the founder of the Sunni dynasty and a liberatorwho is said to have come from 'Mali' (Rose and Stoller 1989, 64). Different sources and chronicles differ with respect to the relationship existing between Ali Kolon and the king of Mali. Al-Sadi claims that Ali Kolon was the son of the ruler of the Za, Yasiboi, who lived in Mali as hostage and liberated his people from foreign domination (Ajayi and Crowder 1985;Hunwick 1972 and 2000;LansineKaba, 1977, 1978, 1984; Levtzion and Hopkins 1981; Ki-Zerbo 1997; Dupuis-Yakouba 1911; Humphrey 2001; Kake 1976; and West Africa to 1800 class, note of week VI). 
Lange maintains that Ali Kolon was born and grew up in Mali where he worked as a servant in the Sultan palace. In his expansion of the subject, Lange defends the unclear view of who the alleged founder of the Sunni dynasty was and when he lived. On the other hand, he stresses that it is well-established that in the fourteenth century the Middle Niger was under the sway of Mali. Information provided by IbnKhaldun makes it likely that the Keitas incorporated the kingdom of Gao into their empire at the end of the thirteenth century (Lange 1994, 295).

Lange's position raises many questions related to the time the Sunni came to power and their relation to the Keita dynasty of Mali. He leaves unresolved different views defended by (1) the seventeenth-century Ta'rikhs of Timbuktu on the origin of the Sunni and Leo Africanus' insistence on the Libyan (Berber) origin of Sonni Ali, (2) the conclusions of the texts produced by the historians of Timbuktu and the author of the eighteenth king/fourth Muslim king of the Zas (TF text), and (3) the clarification of inconsistencies found between different oral traditions, especially the Sorko, and the scholarly works of the Timbuktu authors, the author of the TF as well as divergent positions defended by modern scholars of the Middle Age West Sudan. In spite of the status of the problems that he brings to the attention of historians of Africa, especially Middle Age West Sudan, we give him credit for stimulating a deep conversation that will attempt to resolve the question around the names, number of rulers (28 or 33) and the time given by the kinglist between Kosso-Dare (the first king of Gao-Sane) and Sonni Ali.

Historians agree that Sonni Ali Ber was the founder of the Sonni dynasty and of the empire of Songhay. He was raised in a Songhay traditional environment and he was a great defender of his ancestral religious beliefs. Historians recognize in him a ruler who promoted the cohabitation between Islam and his ancestral religious beliefs. His birth was surrounded with mystery and anticipation. His mother was not a Songhay, but a foreign princess given to marriage to a certain SonniMadao or SonniSouleymanDama as the historian LansineKaba attests. Certaines sources suggèrentqueSonniMadaoouSonniSouleymanDama (ouDandi) enfant à Sonni Ali Ber. Les historiens ne se sont pas encore tout à fait misd'accordsurce point. Cependantil y a unecertaine animate que la reine, épousepréferée de Dandi, étaituneceratine Baraka, cellequel'onappelait 'la princesseétrangère' (Kaba 1977, 18). He came to power in 1464, expanded the power and influence of Songhay by initiating the Songhay wars of expansion. SonniAli, plus connu sous le nom d'Ali-Ber, fut le vraifondateur de l'EmpireSonghay. Pendant les vinght-huitannées de son règne (1464-1492), ilconquitl'immenseterritoireque se successeurs, les Askia, allaient organizer et diriger pendant un siècle. Il porta la guerre danstoutes les directions etprincipalementcontre les deuxgrandespuissancesnigériennes, les Touareg et le Mossi. A sa mort, ilétait le maître d'un empire qui s'étendait du Dendi au delta central du Niger ... Il futl'un de rares chefs du Sudan à s'oppposer à l'Islam. Il introduisitdans les croyanceset les rites du Songhay les elements d'ésoterismearabe qui le marquent encore profondement de nosjours(Kaba 1977, 13-15). Under Sonni Ali Ber leadership, the Songhay changed their expansion tactic: from raids to territorial occupation. He reorganized the army, introduced an elite cavalry, known for its speed and military toughness. This new military unity turned out to be all over the Niger regionthe principal military force in Middle Age West Sudan. Known as warriors from Kukiya, the Sonni, under Sonni Ali Ber, conquered Timbuktu (1468), Jenne (1471), part of Macina, and the Hombori (1475-85). From 1486 to 1490, his military campaigns were directed against the Dogon, Peuhl, Touareg and Muslims from Gao. By defeating the Mossi king, Nasere I, in 1483, Sonni Ali Ber put an end to the Yatenga'sincursions into the Niger valley (Caillie 1830, Dupuis-Yakouba 1911, Ki-Zerbo 1997, Humphrey 2001, Hunwick 1985, Kake 1976, and Kaba 1977).

These first Sunni military expeditions give us the chance to look deeper beyond the Sunnis' rise and capture the outside factors that help to their independence, or as al-Sadi asked: were they the only opponents of Mali? Most likely they were in one-way or another. But the Sunnis cannot possibly have been descendants of the Zas because this latter fought against foreign oppressors and prided themselves on their patriotic deeds, which could have caused the Sunnis to adopt the Zas' illustrious titles. Hence the relations between both groups have to be otherwise conceived. The TF text has it that the Sunnis were brought up at the court of Mali but they were not governors. This stance is supported by the later narrative on the eighteenth king/fourth Muslim king of the Zas (TS), which depicted Ali Kolon as a Songhay patriot who freed his people and nation from Mali. The Sunni title, as suggested by the TF, may imply an early deep commitment of the Sunnis towards Islam, which seems to derive from the Arabic sunni (a follower of the sunna [of the prophet Mohamed]). Therefore the Sunni may stand as followers of the Almoravid orthodoxy. Some historians think that such a hypothesis seems to force the note, lest we forget Sonni Ali Ber and the Sunnis deep attachment to their traditional ancestral religion. 
Sonni Ali Ber, known also as the great, accommodated Muslim traders to live side by side with his people. His stand did not mean that he was abandoning his ancestral religious practices for Islam, rather it was for political and economical purposes, suggests Hunwick. There is also the need to consider two other reasons Sonni Ali Ber's son, SonniBaru ${ }^{7}$, lost the throne to one of his lieutenant, a Soninke of origin from Fouta Jallon, Mohammad AboubekrToure (1493-1528): the bad treatment the Sunnis inflicted to Muslims and Baru's attempt to reestablish his ancestral religious beliefs. Mohammad Toure took the throne by a military coup. Les erudits de l'Islamfirentmaintes efforts pour essayer de le convaincre de devenirunvraimusulman, maisn'yparvinrent pas. Un group de musulmanss'organisaetdecida de le renverser. Les forces "revolutionaires" étaient conduits par l'un des propres lieutenants de Sonni Ali: Mohamed Toure, de l'ethnie de Soninke (Kake 1976, 11).

At the battle of Anfao (1493),the forces of Mohammad AboubekrToure defeated the army of SonniBaru: the Sunnis' defeat meant the end of their dynasty and the advent of the Askias - the third and final dynasty of Songhay. This dynasty, the Askias, was named after Mohammad Toure, who took the name Askia after his forces defeated the Sunnis. The Askias were Muslim Mande-speaking people who have governed ancient Mali and opposed the pagan Songhay rulers. Askia Mohammad Toure is credited for bureaucratizing and for extending the empire borders to Kanem-Bornu and the Haussa states of the east upper Senegal River, including the salt-mining of Teghaza (Kake 1976, Ki-Zerbo 1997, Caillie 1830, Dupuis-Yakouba 1911, West Africa to 1800 class, note week VI). It is during the reign of Mohammad Toure that the empire reached the height of its power (Hunwick 1966, 1972; Rouch 1953; Hama 1968). Before the ascendance of the Askia dynasty to the throne of Songhay, historians agree that Islamic influences have been in the region for at least seven hundred years. In spite of the lack of record and almost no serious archeological work, it seems likely that Muslim merchants of Arab, Berber and probably Persian origin began trading down ... via Tilemsi valley to the Niger soon after the foundation of the Rustamid state of Tahert in 144/761 (Hunwick 1985, 3). The Askia, known for their dynastic squabbles of successive reigns (AskiaDāwūd (1549-82); Askia Musa, 1528-31; BenganKorei, also known as AskiaMuhammad II, 1531-37; Askia Ismail, 1537-39; AskiaIssihak I, 1539-49), were not able to maintain the peace and prosperity initiated by MuhammedToure.

The dynastic quarrel was followed by raids initiated by the Moroccan army led by sultan al-Mansur on the salt deposits of Teghaza. The situation, which Mohammed Bāni (1586-88) could not contain, culminated disastrously for Songhay under Issihak II (1588-91) when the Moroccan army engaged the Askia first at Tondibi and then at Timbuktu and Gao.Its decline started in late $16^{\text {th }}$ century because of it great size, too large to control effectively. The fight to control the rich Sahara trade was another cause and ultimately the battle of Tondibi against the Moroccans, around 1585, brought Songhay down (lost of salt-mining of Teghaza and Taodeni.This causes the Songhay rulers to retreat southward to the region of Dendi on the Niger where they continued to rule over their own people (Appiah and Gates 2005, 19-20). The complete disintegration of Songhay came in the seventeenth century after their southward flight was followed by internecine conflicts that resulted in the creation of five autonomous principalities. These new autonomous polities never brought peace and prosperity back to Songhay. They were completely disintegrated in the nineteenth century after the French arrived in the region (Appiah and Gates, 2005).

\section{Social order, Mobility, Trade, and Slavery}

Middle Age West Sudan was well known for people's migration, its trade with North Africa, Muslim merchants of Arabs, Berber and probably of Persian origin. Dan Rose and Paul Stoller, on their articulation of the Middle Ages West Sudan migration, point to two main characteristics in Songhay:

(1) the people were always more important than the land, and;

(2) even the most articulated polities descent remained the core of a man's identity (Dan Rose and Paul Stoller, 1989).

This scenario of the demographic mobility includes the more-or-less voluntary and the fully voluntary migration. The more-or-less case shows the people fleeing an enemy, starving people fleeing drought, panic stricken and epidemic and slave raiding. Historians agree that there were less explicit evidence associated to peaceful mobility.

\footnotetext{
${ }^{7}$ After his mysterious death in 1492, Sonni Ali Ber was replaced by his oldest son, SonniBaru. Soon after his enthronement, SonniBaru was challenged by Mohammed Toure on the ground that the animism of his grandfathers was the wrong element to reestablish in the empire. Thus, the war between Mohammed Toure and his Islamic fervor supporters against SonniBaru!
} 
Violent or imposed mobility seemed to be the norm associated to some kind of external superiority, whether racial, religious, cultural, imperial, or some kind of combination of these taking one back to some inexplicit sources in the Middle East, which could infer to a Muslim source.Slavery itself supplies a further illustration of involuntary mobility (Humphrey 2001, 3-4). Fisher Humphrey gives a good summation of social interaction as it was related to slavery with or without peaceful mobility - many sources point to no such peaceful mobility but to violent and imposed mobility. Many reports also seem to point the peaceful settlement, but every now and then an arrow phrase will sleep in to prove just the contrary. In the Borno region for example, the traveler Heinrich Barth reported that Lamino was the deputy of a more senior Borno official: Lamino carried out the orders of his superiors with complete loyalty and ruthless efficiency, and people moved out to escape his heavy-handed authority (Humphrey 2001, 7).

Songhay society was stratified and its exclusivity was also reinforced by a complementary set of ideal standards of behaviour for nobles, for slaves and for non-Songhay(Stoller 1981, 767). The belief that only the noble had the predisposition to govern was central and tightly guarded in Songhay. The point of reference in Songhay political system was the chief-bankwano. This position was closely linked to the sacred powers of lakkal, the wisdom to govern and the ful, the hat of inner strength and determination (Lange 1994, Stoller 1981, Kake 1076, Humphrey 2001, and Hunwick 1985). This chief was a recipient of sacred capacities; he showed and maintained his power and legitimacy over the polity by affirming the belief in his sacredness and displaying his sociopolitical skills to diffuse political networks. Through the exhibition of these skills, the Songhay social interaction map is well understood and exposed. Social inequity was the cement of the Songhay imperial order. Its continuation has been the foundation of the ongoing political legitimacy of Songhay nobles and social order (Rose and Stoller 1988, Stoller 1978 \& 1981). These few different historical analyses and views of the Songhay sociopolitical themes provide us with a clear understanding that space was a powerful political toll in Songhay community.

The Songhay space was also an important inter-regional hub for trade routes. Ibn al-Saghir early account of c.290/902-3 indicates that routes were opened up for trade with bilad al-Sudan and missions were sent southwards. Hunwick, translating Arabic sources of Timbuktu of 1657 and 1669, attests of Gao's commercial international fame (Hunwick 1985). Various accounts of Ibn Battuta talked of the kingdom of Takedda with its important copper mines and a network of trade routes linking Songhayland with Gobir in Hausaland, the Magrib and even Egypt (Fuglestad 1983). This is one area where scholars agree and I will term it common ground. The chief commodity of the region was gold coming from the forest regions of Bambuk and Bure. Important manpower was needed to work in those gold mines. Thus slavery and slaving! By the tenth and eleventh-century, salt commerce was a very important item of commerce at Gao and Kukiya coming down from Tilemsi. That salt could have been traded down the river where Sudanicproducts useful to nomad might be obtained: mats, gourds, wax, honey, iron goods and perhaps cloth. Above all such trade gave increased access to grain (Hunwick 1985, 5). This trade created local wars and raids, some historians maintained, which produced captives traded north as slaves to form an item in the exchanges. Hunwick and Lovejoy suggest that already in second century Islam Muslim Arab merchants went down to trade with Ghana, Mali and maintained the trade with Songhay. The trade was in gold dust, salt and slaves. Slave trade was very attractive for Arabs because they were looking for sources of domestic and military slaves. This point explains partially the implantation of Muslim community at the left bank of the river in Gao (Hunwick 1985, Okihiro 1986). The late arrival of Europeans shifted the slave trade to the Americas until the French, officially, abolished it in 1898. Slavery, however, was one of the social foundation corners of pre-colonial Songhay social order.

Fisher Humphrey and Claude Meillassoux suggest that slavery was caused by many elements sometimes not easy to well grasped but it was power needed for economic expansion. This is the intersection point where slavery and slaving enhance the faltering demographic resources wherever a power center is able to exercise the necessary force (Humphrey 2001; Meillassoux 1991), and without itthere were really few effective means of mobilizing labour for the economic and political needs of the state (Fage 1969, 393-404). Slavery, expands Humphrey, is sub-heading of a broader and deeper African context, the context of demographic resources and population mobility (Humphrey 2001, 1). In their discourse of the complicated subject of slavery, many historians defend the idea of free migration, but as a result of military success of some entities. On slavery connected to free mobility, important ideas could be regrouped in three points: 
(1) although, it was, in Africa, one important mean of enhancing demographic resources, the practice was an unsatisfactory policy. Slave-raiding was a messy business, dangerous in its nature, destructive for neighboring societies who could have become trading partners. It dislocates trade, travel, and other productive activities;

(2)in contrast to the idea of peaceful immigration, there were such situations as the bloody-and-thunder glory of slaving and its benefits, and;

(3) the booming town of Middle Age West Sudan, a land flowing with salt and kola, with pious learning and seasoned with eunuchs became a space for individual and group initiative.The black African Muslim community, in spite of its Islamic law againstenslaving fellow-Muslims, was not spare from the practice.

Ki-Zerbo and Niane suggest that the Songhay Empire lasted nearly eight hundred years because of a triple pole: its governmental/social structure, its religious cohesion, and its intellectual development. The royal government was formed by top different office holders sitting in the imperial council and dealt with different matters. They were a chancellor-secretary, the hikoy (master of water or commander of the fleet), the farimondzo (minister of agriculture), the saw farma (commissioner of forests), the kalisafarma (finance minister), the balama (commander of the army), and the Korifarma (minister in charge of white foreigners). The kalisafarma was backed by the werneyfarma (in charge of property), the banafarma (responsible for wages), and the doyfarma (in charge of purchases). The provinces and vassal or tributary countries were governed by local law and under the watch of a faithful slave or a local leader who pledged his loyalty to the throne of Gao/Kukiya (Ki-Zerbo and Niane 1997; West African to 1800 class note Week VI).

The religious and intellectual poles were intertwined. Both used the Arabic language. Islam was an asset and a liability for the Songhay because it was the reason of uneven progress and did not take deep root during the Sonnis hegemony. In urban cities, it was the privilege of a minority who assumed the Islamic message and became the leading thinkers ... Islam thus was established in urban spheres of power(Ki-Zerbo and Niane 1997, 87). Timbuktu stood as a model and became the holy city of the Middle Age West Sudan. Its elites were trained in the universities of Karawiyyin in Fez and Azhar in Cairo. It was made possible by the surplus of the economic power and development. This prosperity also attracted many scholars from the Sudan, North Africa and even the near East ... The two historical Ta'rikhs produced by intellectuals of the Songhay empire testify to the level reached by these universities which were less strict organized than in North Africa. They were indepenedent schools and open mosques (Ki-Zerbo and Niane 1997, 86). In sixteenth century Timbuktu, there existed one hundred and eighty koranic schools and thousands of students from far and near. The study existed at two levels: the koranic school for memorization of texts and the madrasa, and the university learning for interpretation and creative work. The Muslim humanities' include theology (tawhih), exegesis (tafsir), traditions (hadith), jurisprudence (fikh), grammar, rhetoric, logic, astrology, astronomy, history and geography. But the Islamic approach taken in the studies left little to no room for the sciences (Ki-Zerbo and Niane 1997).

\section{Conclusion}

This historiography has been not an exhaustive enterprise, but a partial reading of few general and particular works of some historians of Africa on the Songhay Empire of the Middle Age West Sudan. This reading on the Songhay Empire was engaging, helped us understand the complexity of scholarship and sent out an urgent call to all students of Africa to engage in the enterprise, which will illuminate the African past. Different unresolved tensions and hypothesis articulated by historians of Africa showed the need to level the deep gap between oral tradition, chronicles, traditions and different accounts given by the various array of sources known and to be discovered.The Songhay Empire, from its humble beginning to its decline, has given itself as a revolutionary group that sought to assert its independence and expand its influence by controlling the rich Saharan trade of Middle Age West Sudan. Their arrival in the region antedated the second half of the fourteenth century based on the travel accounts of Ibn Battuta and IbnKhaldun. Led by strong leaders from the Dia dynasty, the Sunnis and finally the Askias, the Songhay emerged from the declining Mali as a new political and military unit that built one of the most powerful and lasting empires of Middle Ages West Sudan. The first dynasty, the Dia, has remained in power and intact until the fourteenth century. The second dynasty, the Sonni, reached the zenith of its power under Sonni Ali Ber, who expanded the influence and power of Songhay in the region. The third and last dynasty, the Askia founded by Mohammed Toure, bureaucratized the empire and extended its borders. Most historians of Africa showed some signs of agreements on different aspects of Songhay life, but the debate between Hunwick and Lange left us with more questions on the time, kings' names and the dynastic shift between the Dia and the Sonnis. 
The Sonni title and its attribution to Muslim Arabs Sunni opened itself as another interesting filed of research. The Songhay governmental, political and social order was built on a very strong patrilineal lineage, which was also a reflection of its stratified society. Trade with far and neighboring people reached its height in the fifteenth and sixteenth century. The extended demand to keep political stability, in gold and agricultural products increased the already existing slave trade (Hunwick 1985, Okihiro 1986). The rich Saharan Trade, which was Songhay's rise to power, was also the reason of its decline as it became intertwined with dynastic squabbles of successive reigns. Songhay history is starting to unfold the glory past of Middle Ages West Sudan; as one Songhay wiseman put it: today you are learning about us, but to understand us, you will have to grow old with us.

\section{Bibliography}

A.J. Ajayi and Michael Crowder. Eds. Historical Atlas of Africa. (Cambridge: Cambridge University Press; $1^{\text {st }}$ edition ,1985).

Cheikh Anta Diop.Antériorité des Civilizations Nègres: MythesouVéritéHistorique? (Paris: PrésenceAfricaine, 1967).

Cheikh Anta Diop.Afrique Noire Pré-Coloniale. (Paris: PrésenceAfricaine, 1987).

Kwame Anthony Appiah and Henry Louis Gates. Africana: The Encyclopedia of the African and AfricanAmerican Experience. Vol 5. (Oxford: Oxford University Press, 2005).

Edward W. Bovill. The Golden Trade of the Moors.(New York: Oxford University Press, 1968).

René Caillié. Travels through Central Africa to Timbuctoo; and across the Great Desert, to Morocco, performed in the years 1824-1828. Vol. II. (London: Colburn \& Bentley, 1830.)

Martin Chanock and Sally Falk Moore. Law As Process: An Anthropological Approach. Series: Classics in African Anthropology. (Münster, Germany: LitVerlag, 1972).

J.D. Fage. A History of West Africa. (Cambridge: Cambridge University Press, 1969.)

Humphrey J. Fisher.Slavery in the History of Muslim Black Africa: The Institution in Saharan and Sudanic Africa and the Trans-Saharan Trade. (London: C Hurst \& Co Publishers Ltd, 2001).

F. Fuglestad. A History of Niger, 1883-1900. (Cambridge: Cambridge University Press, 1983.)

F. Fuglestad. "A reconsideration of Haussa Before the Jihad." In Journal of African History.19, 3(1978), 319-339.

S.M.X. Golberry. Travels in Africa during the Years 1785, 1786, 1787 ... Trans. F.Blagden (2 vols). (London: B.McMillan, 1802).

Thomas A. Hale and NouhouMalio. Scribe, Griot and Novelist: Narrative Interpretations of the Songhay Empire (Gainesville: University of Florida Press, 1990).

B. Hama. Histoire des Songhay: Publication de la République du Niger. (Liege: Université de Liège, 1968.)

B. Hama. L'histoiretraditionnelle d'un peuple: Les Zarma-Songhay. (FeniXXrééditionnumérique, 1967.)

Herodotus. The History of Herodotus. Vol. 1.Translated by George Rawlinson. (New York: Tudor, 1928).

John O. Hunwick. Shari'a in Songhay: the Replies of Al-Maghili. (Series: FontesHistoriaeAfricanae). (Oxford: Oxford University Press, 1985).

John O. Hunwick etAlii. Eds. The Cloth of Many Colored Silks: Papers on History and Society Ghanaian and Islamic in Honor of Ivor Wilks. (Evanston, IL: Northwestern Univ. Press, 1996).

John O. Hunwick and O'Fahey. Eds. Arabic Literature of Africa: The Writings of Eastern Sudanic Africa to c. 1900. (Evanston, IL.:Brill Academic Publishers, 1997).

John O. Hunwick. Timbuktu and the Songhay Empire: Al-Sa 'Di'sTa'Rikh Al-Sudan Down to 1613 and Other Contemporary Documents (Islamic History and Civilization). $2^{\text {nd }}$ ed. (Evanston, IL.: Brill Academic Publishers, 1999).

John O. Hunwick. West Africa, Islam, and the Arab World: Studies in Honor of Basil Davidson.(Princeton, NJ: Markus Wiener Publishers, 2010).

Timothy Insoll. "Looting the antiquities of Mali: the story continues at Gao." Antiquity 67: 256 (Sept 1993).

LansineKaba. Evolution of Islam in West Africa: The Wahhabi movement and its contribution to political development, 1945-1958. (Evanston, IL.: Northwestern University Press, 1972).

LansineKaba. Sonni Ali-Ber: Fondateur de l'Empire Songhay. (Series: Grandes Figures Africaines, French Edition). (Dakar, Sénégal: Nouvelles Editions Africaines, 1977).

Ibrahima Baba Kaké.Askia Mohamed: L'Apogée de l'Empire Songhay. (Paris: ABC, 1976). 
Joseph Ki-Zerbo and DjiBrilTamsirNiane. Eds. UNESCO General History of Africa, Vol. IV.: Africa from the Twelfth to the Sixteenth Century. (Oakland, California: University of California Press, 1998).

Joseph Ki-Zerbo. Ed. UNESCO General History of Africa, Vol. I, Abridged Edition: Methodology and African Prehistory. (Oakland, California: University of California Press, 1997).

Dierk Lange. Ancient Kingdoms of West Africa: Africa Centred and Canaanite Israelite Perspectives. $1^{\text {st }}$ ed. (Dettelbach, Germany: J.H.Roll GmbH, 1974).

Dierk Lange. 'From Mande to Songhay: Towards a political and ethnic history of medieval Gao', JAH, 35 (1994), 275-300.

Dierk Lange. Chronologieet Histoire d'un RoyaumeAfricain. (Wiesbaden, Germany: F. SteinerVerlag, 1977).

Dierk Lange.A Sudanic Chronicle: The Borno Expeditions of IdrisAlauma (1564-1576) According to the Account of Ahmad b. Furtu: Arabic Texts. (Wiesbaden, Germany:F. Steiner Verlag, 1987)

NehemiaLevtzion and J.F.P. Hopkins. Eds. Corpus of Early Arabic Sources for West African History. $1^{\text {st }}$ edition. (New York: Markus Wiener Publishers, 1981).

John Lonsdale. The State and Social Processes in Africa. (s.n, 1981)

Irving L. Markovitz. Power and Class in Africa: An Introduction to Change and Conflict in African Politics. (Upper Saddle River, N.J.: Prentice Hall, 1977).

PekkaMasonen. The Negroland Revisited: Discovery and Invention of the Sudanese Middle Ages. (Helsinki: Finnish Academy of Science and Letters, 2000).

Claude Meillassoux. Légende de la Dispersion des Kusa (Epopée Soninke) (Dakar: IFAN, 1967).

Claude Meillassoux. L'Anthropologie de l'Esclavage: le Ventre de Feretd'Argent. (Paris: Presses Universitaires de France, 1986).

SékénéModyCissoko.Tombouctoetl'Empire Songhay: Epanouissement du Soudan Nigérien aux XVe-XVIe Siècles. (Paris: L'Harmattan, 1996).

Pierre Montet. Sciences etAvenir, no. 56, October 1951.

Ari Nave. "Songhai Empire" in Africana, The Encyclopedia of the African \& African American Experience, Kwame Anthony Appiah, and Henry Louis Gates, Jr. eds., (New York: Oxford: University Press, 2005).

Gary Y. Okihiro, ed. In Resistance: Studies in African, Caribbean, and Afro-American History. (Amherst, MA.: University of Massachusetts Press, 1986).

Olivier Pétré-Grenouilleau. Les TraitesNégrières. (Paris: Galimard, 2004).

Dan Rose. Patterns of American Culture: Ethnography and Estrangement.(Philadelphia: University of Pennsylvania Press1989).

Abd al-Raḥmānibn'AbdAllāhSa'dī.Tārīkh al-Sūdān. $3^{\text {rd }}$. edition (Paris: A. Maisonneuve, 1964).

Abd al-Raḥmānibn'AbdAllāhSa'dī.Tārīkh al-Sūdān.Traduit de l'Arabe par O. Houdas, avec la collaboration de Edm. Benoit. Documents arabesrelatifs à l'histoire du Soudan-Tarikhes-Soudan.(Paris: A. Maisonneuve, 1964).

Jean Rouch. La Religonet la Magie Songhay. Paris: PresseUniversitaire de France, 1960.

Jean Sauvaget. Notes préliminariessur les épitaphes de Gao. La Revue des Etudes Islamiques, pp. 7-8, in 1948.

Jean Sauvaget. Les EpitaphesRoyales de Gao. Al-Andalus, XIV, 123-41, in 1949.

Kevin Shillington. History of Africa (New York: Palgrave, 2005).

WoleSoyinka. Kongi's Harvest: AThree Crowns.(Oxford: Oxford University Press, 1967).

Paul Stoller and Cheryl Olkes. "Bad Sauce, Good Ethnography. "Cultural Anthropology 1, no. 3 (1986): $336-352$.

Paul Stoller. Fusion of the Worlds: An Ethnography of Possession Among the Songhayof Niger 1st Edition(Chicago: University of Chicago Press, 1981).

Godfrey N. Uzoigwe. Ed. Anatomy of an African Kingdom: A History of Bunyoro-Kitara. (New York: NOK Publishers Intl., 1980).

West Africa to 1800, class note, Howard University, Washington, DC., Fall 2015.

E.A. Wrigley. Population and History.(New York: World University Library, 1971).

Dupuis-Yakouba. Les Gowou Chasseurs du Niger:LégendesSongaï de la Région de Tombouctou.(Paris: Ernest Leroux, 1911). 